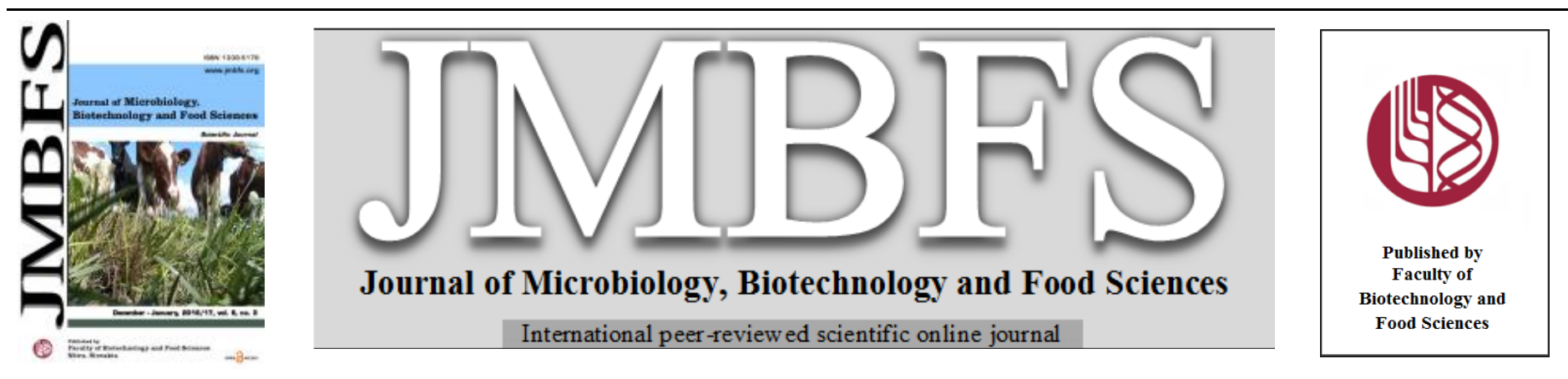

\title{
EFFECT OF ROSELLE CALYX EXTRACT ON GINGIPAIN ACTIVITY, PRODUCTION OF INFLAMMATORY CYTOKINES, AND ORAL BACTERIAL MORPHOLOGY
}

\section{Herastuti Sulistyani, Mari Fujita, Futoshi Nakazawa*}

Address(es): Professor, Futoshi Nakazawa,

Health Sciences University of Hokkaido, School of Dentistry, Department of Oral Microbiology, 1757 Kanazawa, Ishikari-Tobetsu, Hokkaido 061-0293, Japan, Tel: +81 133232484.

*Corresponding author: nakazawa@hoku-iryo-u.ac.jp

doi: $10.15414 / j m b f s .2016 / 17.6 .3 .961-965$

\section{ARTICLE INFO}

Received 14.1.2016

Revised 24. 10. 2016

Accepted 25. 10. 2016

Published 1. 12. 2016

Regular article

oPEN $\odot$ ACCESS

\begin{abstract}
This study to investigate the effect of roselle calyx extract on gingipain activity, production of inflammatory cytokines, and oral bacterial morphology. The inhibitory effect of roselle calyx extract (RCE) on Arg- (Rgp) and Lys-gingipain (Kgp) was evaluated using synthetic substrate colorimetric assay with a 96-well microtiter plate. RCE with various concentrations was tested for determination of interleukin (IL)-6 and IL-8 produced from KB cells stimulated with heat-inactivated $P$. gingivalis. The production of IL-6 and IL-8 was quantified using an ELISA kit. The morphological alterations in cells of $S$. mutans and $P$. gingivalis after treatment with RCE were studied using scanning electron microscopy (SEM). RCE could inhibit both Rgp (90\%) and Kgp (70\%) activities significantly at concentrations lower than the minimum inhibitory concentration (MIC) $(2.2 \mathrm{mg} / \mathrm{mL})$. Furthermore, the production of IL- 6 and IL-8 from KB cells stimulated with $P$. gingivalis was significantly inhibited by RCE at $6 \mathrm{~h}$ after exposure, in a dose-dependent manner. After treatment with RCE, the morphological alterations were observed in cells of $S$. mutans and $P$. gingivalis by using SEM. The ability of RCE to inhibit gingipain activity and production of inflammatory cytokines indicates that RCE could be considered for prevention and clinical treatment for periodontitis.
\end{abstract}

\section{INTRODUCTION}

Periodontitis is an oral infectious disease caused by bacteria or groups of bacteria. The bacteria accumulate on the surface of the tooth and cause the destruction of periodontal connective tissue and alveolar bone, resulting in tooth loss (Haake et al., 2006; Darveau, 2010). It was reported that a group of bacteria, such as Porphyromonas gingivalis, Tannerella forsythia, Aggregatibacter actinomycetemcomitans, Treponema denticola, and Fusobacterium nucleatum may contribute to periodontal diseases. Among these, Porphyromonas gingivalis ( $P$. gingivalis), a Gram-negative, anaerobic, nonmotile rod, is strongly associated with adult periodontitis (Slots et al., 1994). This species is significantly more abundant in diseased sites than in healthy sites (Slots et al., 1999; Haffajee et al.,1994). The presence of $P$. gingivalis is indicative of disease progression risk and reduced levels correlates with successful clinical treatment (Haffajee et al.,1994).

$P$. gingivalis possesses many virulence factors, including gingipains. Gingipains are trypsin-like cysteine proteinases classified into two groups, the argininespecific cysteine protease (Rgp) and the lysine-specific cysteine protease (Kgp), based on substrate specificity. Rgp activates the blood coagulation system, associated with gingival crevicular fluid production, and initiates the inflammation process (Imamura, 2003). Kgp contributes to a tendency toward gingival bleeding (Imamura, 2003; Potempa et al., 2000). The gingipains have been isolated from culture supernatants, vesicle membrane fractions, and cell extracts (Chen et al., 2001; Yamanaka et al., 2007).

Epithelial cells, which line mucosal surfaces and provide an important mechanical barrier, play a communication role for the host as microorganism sensors and signal providers. These cells can activate mucosal inflammatory and immune responses(Kagnoff $\boldsymbol{e t} \boldsymbol{a l}$., 1997). It has been reported that $P$. gingivalis can bind to and invade human oral epithelial cells (Duncan et al., 1993). An interaction between bacteria and epithelial cells is required for periodontal inflammation (Yumoto et al., 1999). Cytokines, small soluble proteins produced by a cell, play an important role in many biological activities such as inflammation (Okada et al., 1998). Inflammatory cytokines, like interleukin(IL) 6 and IL-8, are induced during the inflammatory process. Some reports showed the involvement of IL-6 and IL- 8 in the pathogenesis of tissue destruction in periodontitis (Yumoto et al., 1999; Okada et al., 1998; Kang et al., 2011). Since gingipains, IL- 6 , and IL- 8 are involved in the pathogenesis of periodontitis, these components could be effective targets for prevention/control of periodontitis.

Roselle calyx extract (RCE), the extract from Hibiscus sabdariffa L. (Family Malvaceae) grows in tropic and subtropic areas. Roselle calyx has medicinal properties and has been reported to contain alkaloids, saponins, and flavonoids such as gossypetine, hibiscetin, and sabdaretine (Hirunpanich et al., 2005; Olaleye et al., 2007). It also contains hibiscus acid, hydroxybenzoic acids, flavonols, anthocyanins, and other polyphenolic compounds (Rodrigues et al., 2011). RCE has been considered to have antihypertensive (Arellano et al., 2004) hepatoprotective (Ali et al., 2003), antihyperlipidemic (Hirunpanich $\boldsymbol{e t}$ al., 2006), antioxidant (Yang et al., 2012), anticancer (Tsai et al., 2014), and antimicrobial (Olaleye et al., 2007; Nwaiwu et al., 2011) properties. It is possible that the use of plant extracts with the ability to inhibit gingipains activity and cytokine production is an alternative strategy for periodontal therapy. Our previous study showed that RCE has antibacterial activity and inhibits biofilm formation. In the present study, we investigate RCE's ability to inhibit gingipains activities and cytokine production stimulated by $P$. gingivalis, and its effect on bacterial morphology.

\section{MATERIAL AND METHODS}

\section{Preparation of the RCE}

We soaked $16 \mathrm{~g}$ powder of dried roselle calyx in $160 \mathrm{~mL}$ ethyl alcohol (Wako Pure Chemical Industries Ltd) with shaking for $24 \mathrm{~h}$ at room temperature. After centrifugation, the extract was lyophilized. Then the extract was dissolved in phosphate-buffered saline (PBS) and the $\mathrm{pH}$ was adjusted to 7.0. The extract was aseptically filtered through a disposable membrane filter unit with a $0.45-\mu \mathrm{m}$ pore size. The extract was stored at $-20^{\circ} \mathrm{C}$ for further use. 


\section{Determination of Rgp and Kgp activity}

The inhibitory effect on Rgp and Kgp of RCE at different concentrations was evaluated by using synthetic substrate colorimetric assay (Yamanaka $\boldsymbol{e t}$ al. 2007; Nakatsuka et al., 2014). Benzoyl-arginine- $p$-nitroanilide (Sigma-Aldrich) and tosyl-glycine-proline-lysine-p-nitroanilide (Sigma-Aldrich), in $100 \mu \mathrm{l}$ of 0.1 $\mathrm{M}$ Tris- $\mathrm{HCl}(\mathrm{pH} 8.0)$ containing $1 \mathrm{mM}$ dithiothreitol were used as substrates (final concentration $0.5 \mathrm{mM}$ ) for Rgp and $\mathrm{Kgp}$, respectively. The substrates were dispensed into the wells of a 96-well microtiter plate. A bacterial cell suspension $(50 \mu \mathrm{l})$ of $P$. gingivalis, $1 \times 10^{8}$ cells $/ \mathrm{ml}$ in PBS and RCEs at different concentrations, were added to the substrate and incubated at $37^{\circ} \mathrm{C}$ for $50 \mathrm{~min}$. The optical density, OD, of each well was measured by microtiter plate reader at a wavelength of $405 \mathrm{~nm}\left(A_{405}\right)$. Relative enzymatic activity was determined as follows: [ $\left(A_{405}\right.$ with bacterial cells and RCE $-A_{405}$ of control) / ( $A_{405}$ with bacterial cells $-A_{405}$ of control)] x 100. Degradation obtained in the absence of the RCE was given a value of $100 \%$

\section{Determination of IL-6 and IL-8 production}

$\mathrm{KB}$ cells (a human mouth epithelial cell line) were grown in a $5 \% \mathrm{CO}_{2}$ incubator at $37^{\circ} \mathrm{C}$ in Dulbecco's modified Eagle's medium (DMEM, Sigma-Aldrich, USA) supplemented with $10 \%$ fetal bovine serum (FBS), penicillin $(100 \mathrm{U} / \mathrm{ml})$, streptomycin $(100 \mu \mathrm{g} / \mathrm{ml})$, and amphotericin B $(100 \mu \mathrm{g} / \mathrm{ml})$. After washing twice with PBS, the cells were detached from the cultured plate and then diluted to obtain $1 \times 10^{5} / \mathrm{ml}$. A cell suspension $(100 \mu \mathrm{l})$ was cultured in a 96 -well plate and incubated to about $90 \%-100 \%$ confluence. Bacterial cells of $P$. gingivalis $(1 \mathrm{x}$ $10^{8} \mathrm{cfu}$ ) were suspended in serum-free DMEM and heat-inactivated at $80^{\circ} \mathrm{C}$ for $30 \mathrm{~min}$ before infection of KB cells. RCE in various concentrations and $60 \mu 1$ of the bacterial suspension were incubated with $\mathrm{KB}$ cells at a multiplicity of infection (MOI) of 200 at $37^{\circ} \mathrm{C}$ in $5 \% \mathrm{CO}_{2}$. After $6 \mathrm{~h}$, the supernatants were collected and stored at $-20^{\circ} \mathrm{C}$ for cytokine assays. The levels of cytokine in the culture supernatant were determined by ELISA kit (Thermo, USA) according to the manufacturer's instructions. Briefly, the lyophilized standard or RCE was placed on a 96-well strip plate precoated with anti-human cytokine. Afterward, biotinylated antibody reagent was added to each well, followed by streptavidinhorseradish peroxidase solution. Tetramethylbenzidine (TMB) substrate was added and the reaction was stopped by adding stop solution containing $0.16 \mathrm{M}$ sulfuric acid. The absorbance was measured on a plate reader at $450 \mathrm{~nm}$.

\section{Examination of bacterial morphology with Scanning Electron Microscopy}

A scanning electron microscopy (SEM) was performed to examine the changes of bacterial morphology after treatment with RCE. In this study, S. mutans ingbritt and $P$. gingivalis ATCC $33277^{\mathrm{T}}$ were used. Bacterial suspensions were adjusted to reach OD 1.0 at $600 \mathrm{~nm}$ in PBS after overnight culture and washing. These suspensions were layered on cell culture coverslip disks (Thermo Scientific, Rochester, NY, USA) by soaking for $2 \mathrm{~h}$ in anaerobic conditions. The layered disks were washed three times and then treated either with RCE at three times minimum inhibitory concentration (MIC) $(21.6 \mathrm{mg} / \mathrm{mL})$ or with PBS for 1 $\mathrm{h}$ or $2 \mathrm{~h}$ at room temperature. After being washed, they were fixed in $2.5 \%$ glutaraldehyde in $0.1 \mathrm{M}$ phosphate buffer $\left(\mathrm{pH} \mathrm{7.4)}\right.$ ) at $4^{\circ} \mathrm{C}$ for $24 \mathrm{~h}$. The resultant glutaraldehyde-treated layered disks were then washed and dehydrated in ethano (50, 70, 80, and $90 \%$ successively), each for $10 \mathrm{~min}$, and finally three times with $100 \%$ ethanol for 20 min each. They were dried by the $\mathrm{CO}_{2}$ critical-point drying technique (HCP-2, Hitachi, Tokyo, Japan), coated with gold in vacuum (Eiko, IB-3 ion coater, Japan) and examined using SEM (Hitachi S-3500N, Japan).

\section{Statistical analysis}

Statistical analysis was performed using SPSS 21 software. Results were obtained in triplicate and were expressed as mean \pm standard deviation (SD). The significance of the differences between groups was determined using independent $t$-test with a value of $p<0.05-0.01$; the effect of RCE on $P$. gingivalis-induced IL-8 expression in KB cells was determined using one-way analysis of variance (ANOVA) followed by Bonferroni post hoc test.

\section{RESULTS}

\section{Effect on Rgp and Kgp activity}

The effect of RCE on Rgp and Kgp activity was evaluated by colorimetric assay using synthetic substrates (Figure 1). The present study showed that RCE exhibited inhibitory effect on both Rgp and Kgp activity in a dose-dependent manner. RCE reduced the activity of Rgp about $60 \%$ at $0.6 \mathrm{mg} / \mathrm{mL}, 80 \%$ at 1.1 $\mathrm{mg} / \mathrm{mL}$, and $90 \%$ at $2.2 \mathrm{mg} / \mathrm{mL}$. The reduction in Kgp activity was about $50 \%$ at $0.6 \mathrm{mg} / \mathrm{mL}, 60 \%$ at $1.1 \mathrm{mg} / \mathrm{mL}$, and $70 \%$ at $2.2 \mathrm{mg} / \mathrm{mL}$. The differences in gingipains activity between the untreated and treated groups were statistically significant $(p<0.05)$.

\section{Effect on IL-6 and IL-8 production}

We evaluated the effect of RCE at various concentrations on the production of IL-6 and IL- 8 by KB cells stimulated with the heat-inactivated $P$. gingivalis. In Figure 2, the levels of IL-6 (Figure 2A) and IL-8 (Figure 2B) produced by KB cells were significantly reduced by treatment with RCE in a dose-dependent manner $(p<0.01)$ with similar reduction patterns.

\section{Effect on bacterial morphology}

Figure 3 shows the morphological alteration of $S$. mutans and $P$. gingivalis after treatment with RCE for $1 \mathrm{~h}(3 \mathrm{E}$ and $\mathrm{G})$ and $2 \mathrm{~h}(3 \mathrm{~F}$ and $\mathrm{H})$ compared to the structure of the controls ( $3 \mathrm{~A}, \mathrm{~B}, \mathrm{C}$, and D). Bacterial cells of $S$. mutans and $P$. gingivalis in the control group had regular shapes and smooth surfaces. After treatment with RCE, some $S$. mutans cells showed irregular changes such as enlargement and clumping of cells. In $P$. gingivalis, treatment with RCE caused aggregation and distortion of cells. These morphological alterations increased after 2-h treatment.
A

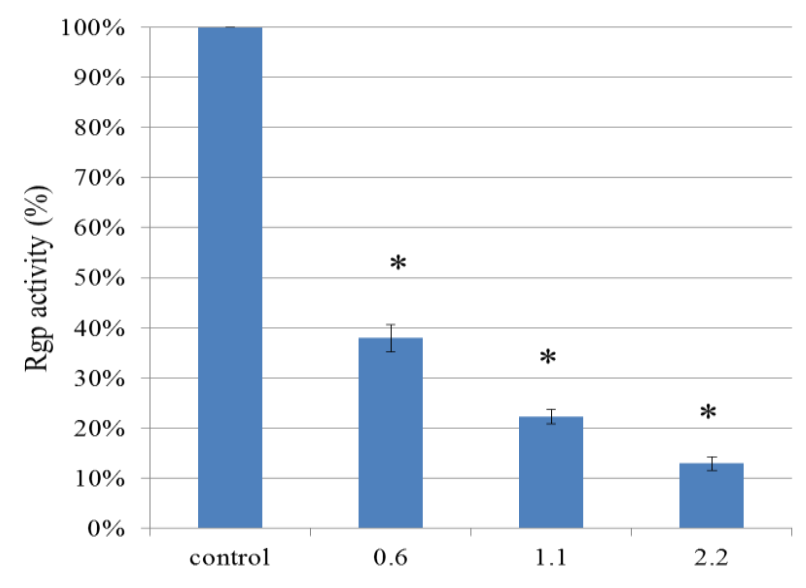

B

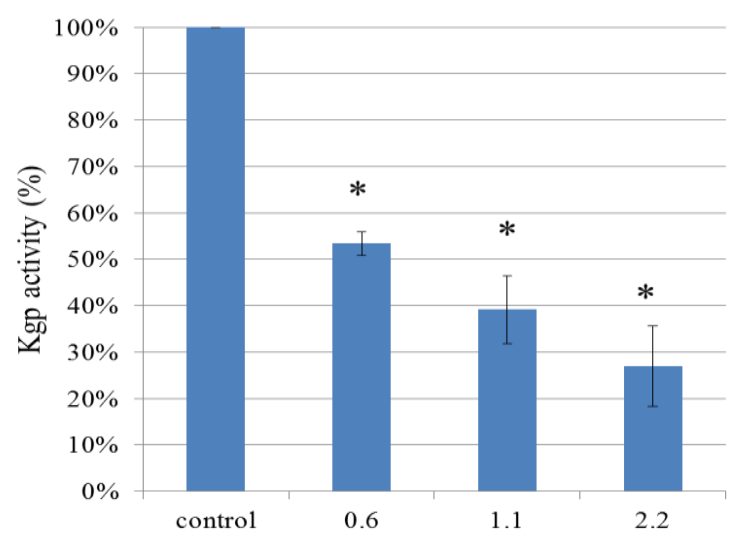

Concentration of RCE $(\mathrm{mg} / \mathrm{mL})$

Figure 1 Effect of roselle calyx extract on $\operatorname{Rgp}(\mathrm{A})$ and $\operatorname{Kgp}(\mathrm{B})$ activity of $P$. gingivalis. The data was expressed with the mean $\pm \mathrm{SD}$ in triplicate experiment. * $p<0.05$ : significantly different from the control. Control: absence of RCE; Rgp: Arg-gingipain; Kgp: Lys-gingipain; RCE: roselle calyx extract. 
A

\section{IL-6 $(\mathrm{pg} / \mathrm{mL})$}

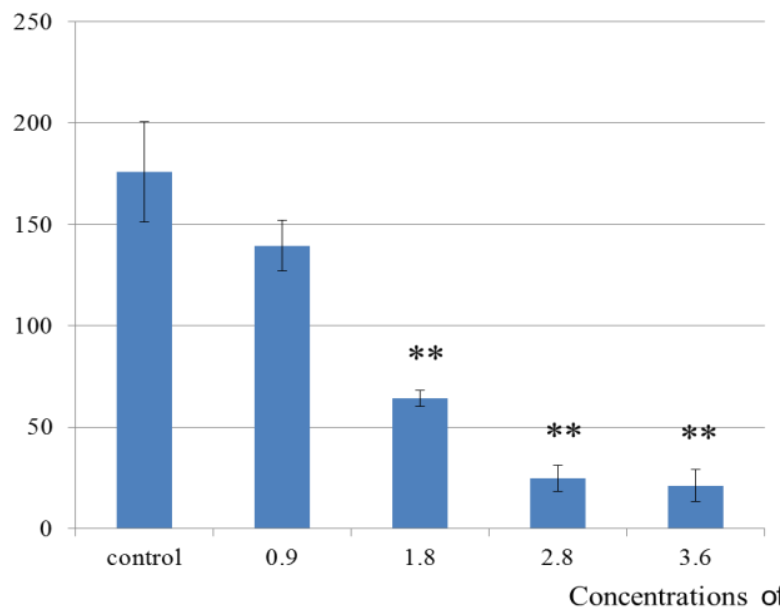

B

\section{IL-8 $(\mathrm{pg} / \mathrm{mL})$}

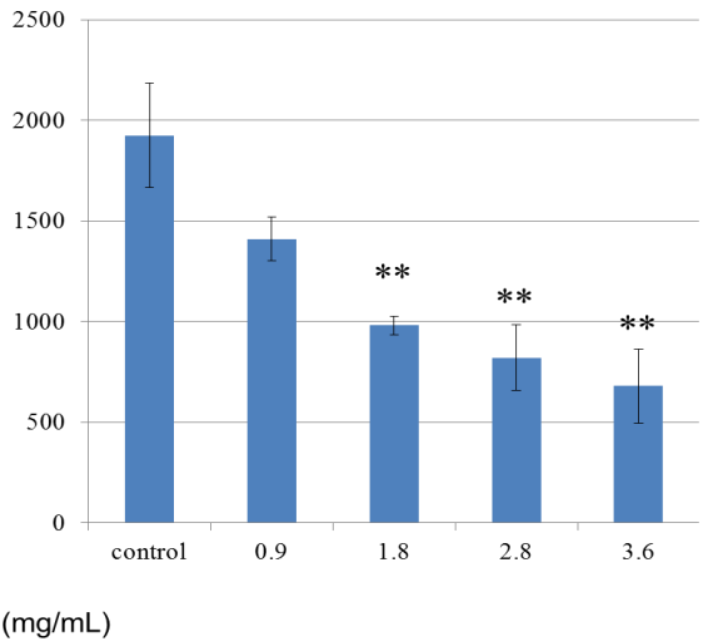

Figure 2 Effect of RCE on P. gingivalis-induced IL-6 (A) and IL-8 (B) expression in KB cells. Control: PBS, P. gingivalis was used at MOI 200. ** $p \leq 0.01$ : significantly different from the control. The data is expressed with the mean \pm SD in triplicate experiment.

\section{DISCUSSION}

Many bacterial species have been identified in periodontal pockets of patients; among those $P$. gingivalis is frequently isolated from the lesions of chronic periodontitis. It was reported that $P$. gingivalis produced major proteinases, Argspecific gingipain (Rgp) and Lys-specific gingipain (Kgp), as virulence factors (Kataoka et al., 2014). Gingipains play a key role in the pathogenic function of $P$. gingivalis. They have the ability to degrade a number of host protein significant for bacterial growth and metabolism, and are responsible for dysregulation of host defensive inflammatory reaction and failure of the host to eliminate bacteria (Olsen et al., 2014)

Gingipains are located on cell surfaces and in culture supernatants, and are related to extracellular vesicles (Chen et al., 2001). The gingipain-loaded outer membrane vesicles may contribute to tissue destruction in periodontal diseases by serving as a vehicle for the antigens and active proteases (Nakao et al., 2014) When separate proteinases with arginine and lysine specificity were isolated from a high molecular mass fraction of the $P$. gingivalis culture fluid, the arginine- and lysine-gingipains were found to contain a hemagglutinin complex. This hemagglutinin may be important in the uptake of hemin via hemagglutination and subsequent hemolysis of erythrocytes (Pike et al., 1994). Arginine-specific cysteine proteinase from the culture supernatant of $P$. gingivalis has the ability to disrupt the functions of polymorphonuclear leukocytes. Further, the enzyme was suggested as a major virulence factor from $P$. gingivalis in the progression of periodontal diseases due to direct destruction of periodontal tissue components and the disruption of the normal host defense mechanism (Kadowaki et al. 1994). The culture supernatant from $P$. gingivalis also induces the disruption of the adhesion and proliferation activities in the endothelial cells; Rgp and Kgp are responsible for these activities (Baba et al., 2002). It is clear that while gingipains are important for the survival of bacteria, they are also pathogenic to the host. Therefore, both Rgp and Kgp activities should be potential therapeutic targets (Olsen et al., 2014).

Results in our study indicate that RCE inhibited the activity of Rgp and Kgp at a sub-MIC concentration (Figure 1). Our previous study reported that the MIC of $P$. gingivalis is $7.2 \mathrm{mg} / \mathrm{mL}$ (Sulistyani et al., 2016). The concentration of RCE used in this study was sub-MIC, therefore the decrease of Rgp and Kgp activity is not because of inhibition of bacterial growth, but because of inactivity of Rgp and Kgp. It was reported that RCE contains polyphenolic compounds (Rodrigues et al., 2011). Previous study showed that cranberry polyphenol was found to inhibit Arg- and Lys-gingipain activities in a dose-dependent manner (Yamanaka et al. 2007). Polyphenols from Myrothamnus flabellifolia Welw (MF) exhibit inhibition of $P$. gingivalis adhesion to epithelial cells, with strong influence against Arg-gingipain. In $P$. gingivalis, the gingipain proteases are suitable targets for polyphenol compounds. Proanthocyanidins react with bacterial surface proteins, leading to an unspecific cross-linking or denaturing effects of adhesion proteins and resulting in inhibition of Rgp (Löhr et al., 2011). From these data we assume that the inhibition effect of RCE on Rgp and Kgp may be due to polyphenol compounds. However, MF exhibits high toxicity, which may limit its clinical use, whereas RCE is safe to use.

Periodontopathogens can promote host inflammatory response by secretion of inflammatory mediators. The association of inflammatory mediators and local tissue destruction in periodontitis has been reported (Okada et al., 1998;
Birkedal, 1993; Bodet et al., 2007). IL-6 is a pro-inflammatory cytokine that has been related to the pathogenesis of periodontal disease. IL-6 expression is increased at sites of periodontal inflammation. It has been suggested as a marker for periodontal disease activity (Irwin et al., 1998) and is involved in bone resorption (Nakashima et al., 2000). It was reported that IL-8, expressed in epithelial cells and macrophages, was observed in gingival inflammation. IL-8 may play an important role in the pathogenesis of periodontitis due to its proinflammatory and neutrophil chemotactic properties (Okada et al., 1998; Kim et al., 2006). The neutrophils are the first line of defense against periodontopathic bacteria. Continuous and excessive IL-8-mediated chemotactic and activation effects on neutrophils may contribute to local destruction of periodontal tissues (Okada et al., 1998).

In the present study, we analyzed whether $\mathrm{KB}$ cells stimulated by the heatinactivated $P$. gingivalis for $6 \mathrm{~h}$ could produce IL-6 and IL-8. Previous study also reported that $\mathrm{KB}$ cells showed cytokine responses after infection with $P$ gingivalis, strongly comparable to that induced by E. coli in vitro (Sandros et al., 2000). The ability of epithelial cells to provoke the cytokine response was related to their adhesive and invasive capacity. In a comparative experiment using a primary culture of pocket epithelium and $\mathrm{KB}$ cells, the result revealed that cytokine responses after $P$. gingivalis and $E$. coli infection were similar. ${ }^{[36]}$ In addition, in vivo study showed that $P$. gingivalis was more potent than $A$. actinomycetemcomitans in inducing proinflammatory cytokines expression. Animals infected with $S$. gordonii, considered a non-pathogenic bacteria, also induced IL-1ß and TNF $\alpha$ but not IL-6 (Kesavalu et al., 2002).

Our study exhibited that the production of IL-8 $(1926 \mathrm{pg} / \mathrm{mL})$ is higher than that of IL-6 (176 pg/mL). Our result is in accordance with previous studies; Yumoto et al. (1999) reported that the level of IL-8 production (approx. $2300 \mathrm{pg} / \mathrm{mL}$ ) by $\mathrm{KB}$ cells stimulated with $E$. corrodens for $8 \mathrm{~h}$ is higher than the level of IL-6 production (approx. $98 \mathrm{pg} / \mathrm{mL}$ ). The level of IL-6 increased $0.5 \mathrm{~h}$ after stimulation; the concentration increased constantly over time and it increased significantly within $4 \mathrm{~h}$. In contrast, the level of IL-8 increased $4 \mathrm{~h}$ after stimulation, and increased aggressively from that point. The production of IL- 8 higher than that of IL-6, was also shown in KB cells infected by $F$. Nucleatum (Kang et al., 2011).

The level of IL-6 and IL- 8 response in KB cells induced by heat-inactivated $P$. gingivalis was reduced after treatment with $\mathrm{RCE}$ at all concentrations used in this study. No cytotoxic effects were detected by WST-1 assay in KB cells treated by $\mathrm{RCE}$ in those concentrations for $6 \mathrm{~h}$ (data not shown). It is indicated that the reduction of IL- 6 and IL-8 production in KB cells treated by RCE is not associated with cell toxicity. In addition, treatment of uninfected KB cells with RCE did not affect cytokine responses (data not shown). It is shown that treatment by RCE does not affect KB cell production of IL-6 and IL-8.

It was reported that RCE contains polyphenols, with flavonoids being the largest of the dietary phenolics group (Kim et al., 2006; Carretero et al., 2008; Medina et al., 2009). Flavonoids have anti-inflammatory effects. Previous study showed that the non-dialyzable material (NDM) cranberry fraction, rich in polyphenolic compounds, could inhibit inflammatory mediator production (Bodet et al., 2007) The mechanism of inhibition may be via a down-regulation of the activator protein-1 (AP-1) activity. AP-1 and nuclear factor- $\kappa \mathrm{B}(\mathrm{NF}-\kappa \mathrm{B})$ are known proinflammatory transcription factors that induce the production of cytokines and other pro-inflammatory molecules (Verri et al., 2012). AP-1 and NF- $\kappa$ B cooperatively regulate the synthesis of $\mathrm{IL}-6, \mathrm{IL}-8$, and $\mathrm{PGE}_{2}$ in the gingival 
connective tissue of patients with periodontitis (Bodet et al., 2007; Kida et al., 2005). Epigallocatechin gallate (EGCG), the major polyphenol component of green tea, inhibits IL-1ß-induced IL-8 production of nasal fibroblast and A549 epithelial cells. The activity might be associated with an intervening reactive oxygen species (ROS) pathway (Kim et al., 2006). Because the main compound of RCE is a flavonoid, we suggested that the flavonoid is involved in the inhibitory effect on IL-6 and IL- 8 in KB cells induced by heat-inactivated $P$. gingivalis. The use of flavonoids as an anti-inflammatory may represent a better pharmacological approach compared to current therapies because flavonoids do not act by a single mechanism and present a better side effect profile, reducing such effects as gastrointestinal and renal lesions (Kida et al., 2005)

The morphologic alteration of oral bacterial species by treatment with RCE has not been reported previously. In this study, we investigated the effect of RCE on $S$. mutans and $P$. gingivalis using SEM. The layered disks of bacteria were treated with RCE at three times MIC for $1 \mathrm{~h}$ or $2 \mathrm{~h}$ under appropriate conditions. We used RCE at this concentration because our purpose was to observe morphologic alterations on the bacteria rather than a reduction in bacteria. In addition, using a concentration of RCE equal to $\mathrm{MBC}$ may have resulted in bacteria detaching from coverslip disks when dead bacteria were processed and removed. The SEM images illustrate the detrimental effects of RCE on the bacteria. S. mutans and $P$. gingivalis in the control group had regular shape and smooth surfaces. After $1 \mathrm{~h}$ of treatment, some cells of $S$. mutans showed irregular shape or clumping. After $2 \mathrm{~h}$, some bacteria showed variation in size, some cells were expansive, and the clumping of cells was more evident than at $1 \mathrm{~h}$ of treatment. Treatment by $\mathrm{RCE}$ on $P$. gingivalis for $1 \mathrm{~h}$ caused aggregation and irregular cell outlines. These patterns were increased on cells treated by RCE for $2 \mathrm{~h}$.

It has been reported that RCE contains phenolic compounds, such as flavonoid The target site of flavonoid might be on membrane cell walls (Cowan, 1999) Our SEM result was in accordance with previous study and showed catechin, the polyphenol compound, caused leakage of intramembranous materials, strong aggregation, and bacterial cell pointing to the likely possibility of membrane fusion. It is well established that membrane fusion by polyethylene glycol, calcium ion, or virions has consistently resulted in the leakage of intramembranous materials and aggregation (Ikigai et al., 1993). SEM analysis of oral microorganisms treated with tea polyphenol showed major structural cell surface changes and irregular forms, with aggregates among cells (Cho et al. 2010). It was reported that damage to bacterial cells might manifest in a few ways, one of which was loss of membrane integrity resulting in leakage of essential intracellular constituents such as inorganic phosphate and proteins. The target of phenols was membrane integrity and leakage (Denyer et al., 1998). From the SEM observations, it seems that RCE binds to the cell membrane, penetrates into the phospholipid bilayer, and disrupts the membrane integrity, resulting in membrane leakage and cell aggregation. We suggested after aggregation, the bacteria will lose integrity and disintegrate, resulting in death However, the mechanisms of RCE on oral bacteria remains unclear, therefore experiments need to be developed.

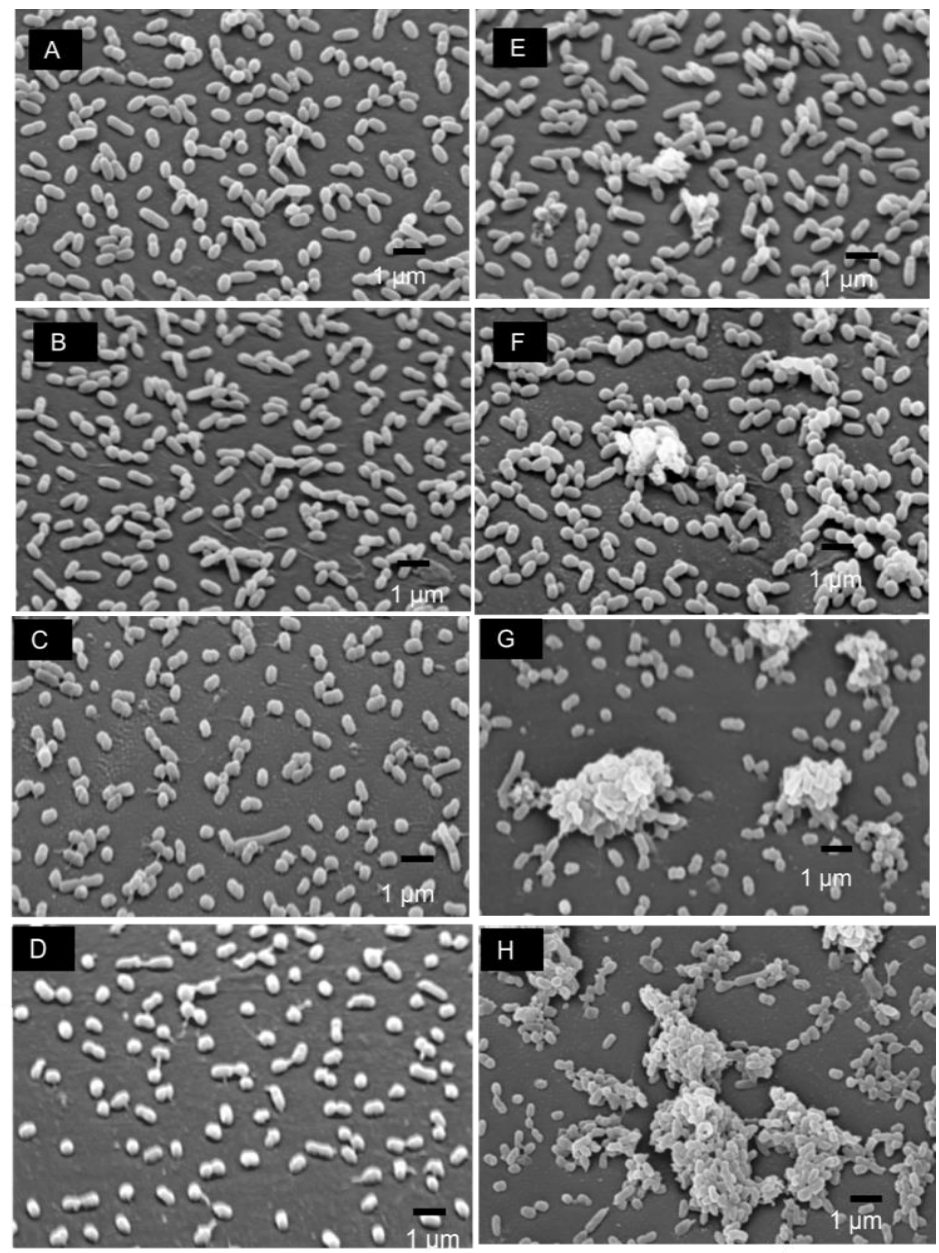

Figure 3 Scanning electron microscope $S$. mutans (A, B, E and F) and $P$. gingivalis $(\mathrm{C}, \mathrm{D}, \mathrm{G}$ and $\mathrm{H})$. A and C: PBS $1 \mathrm{~h}$; B and D: PBS $2 \mathrm{~h}$; E and G: treatment with RCE for $1 \mathrm{~h}$; D and $\mathrm{H}$ : treatment with RCE for $2 \mathrm{~h}$.

\section{CONCLUSION}

Based on our results, RCE could inhibit the activity of Rgp and Kgp, the major proteases of $P$. gingivalis. Moreover, RCE inhibited IL-6 and IL-8 production in KB cells stimulated with the heat-inactivated $P$. gingivalis. From the SEM observations, we suggested that RCE binds to the cell membrane, resulting in membrane leakage and cell aggregation. These data suggest that RCE might have beneficial effect on prevention and clinical treatment for periodontitis.

Acknowledgments: We thank Dr. Yuko Nakatsuka and Akio Maruyama (Health Sciences University of Hokkaido) for technical support. Part of this work was supported by scholarship from Futoku Foundation and Hokkaido Gas Co. Ltd.

\section{REFERENCES}

Ali, B.H., Mousa, H.M., \& Mougy, S.E. 2003. The effect of a water extractand anthocyanins of Hibiscus sabdariffa L. on paracetamol-induced hepatoxicity in rats. Phytother. Res, 3(17), 56-59. http://dx.doi.org/10.1002/ptr.1084 Arellano, A.H., Romero, S.F., Soto, M.A.C., \& Tortoriello, J. 2004. Effectiveness and tolerability of a standardized extract from Hibiscus sabdariffa in patients with mild to moderate hypertension: a controlled and randomized clinical trial. j.phymed,11, 375-382. http://dx.doi.org/10.1016/j.phymed.2004.04.001

Baba, A., Kadowaki, T., Asao, T., \& Yamamoto, K. 2002. Roles for Arg- and Lys- Gingipains in the disruption of cytokine responses and loss of viability of human endothelial cells by Porphyromonas gingivalis infection. Biol. Chem, 383, 1223-1230. http://dx.doi.org/10.1515/bc.2002.135

Birkedal-Hansen, H. 1993. Role of cytokines and inflammatory mediators in tissue destruction. J Periodont Res, 28, 500-510. http://dx.doi.org/10.1111/j.1600-0765.1993.tb02113.x

Bodet, C., Chandad, F., \& Grenier, D. 2007. Cranberry components inhibit interleukin-6, interleukin-8, and prostaglandin $\mathrm{E}_{2}$ production by lipopolysaccharide-activated gingival fibroblast. Eur J Oral Sci, 115, 64-70. http://dx.doi.org/10.1111/j.1600-0722.2007.00415.x

Carretero, A.S., Mejia, M.A.P., Ramirez, S.C., Beltran, R., Villaverde, C.A., Joven, J.,... \& Gutiérrez, A.F. 2008. Selective extraction, separation, and identification of anthocyanins from Hibiscus sabdariffa L. using solid phase 
extraction-capillary electrophoresis-mass spectrometry (time-of-flight/ion trap) Electrophoresis, 29, 2852-2861. http://dx.doi.org/10.1002/elps.200700819

Chen, T., Nakayama, K., Belliveau, L., \& Duncan, M.J. 2001. Porphyromonas gingivalis gingipains and adhesion to epithelial cells. Infection and immunity, 3048-3056. http://dx.doi.org/10.1128/iai.69.5.3048-3056.2001

Cho, Y.S., Oh, J.J., \& Oh, K.H. 2010. Antimicrobial activity and biofilm formation inhibition of green tea polyphenols on human teeth. Biotechnology and Bioprocess Engineering, 15, 359-364. http://dx.doi.org/10.1007/s12257-0090195-8

Cowan, M.M. 1999. Plant products as antimicrobial agents. Clin Microbiol Rev, 12(4), 564-582

Darveau, R.P. 2010. Periodontitis: a polymicrobial disruption of host homeostasis. Nature Reviews/Microbiology $\quad 8, \quad 481-490$. http://dx.doi.org/10.1038/nrmicro2337

Denyer, S.P., \& Stewart, G.S.A.B. 1998. Mechanisms of action of disinfectants International Biodeterioration \& Biodegradation, 41, 261-268. http://dx.doi.org/10.1016/s0964-8305(98)00023-7

Duncan, M.J., Nakao, S., Skobe, Z., \& Xie, H. 1993. Interactions of Porphyromonas gingivalis with epithelial cells. Infection and immunity, 61(5), 2260-2265.

Haake, S.K., Meyer, D.H., Taylor, P.M.F., \& Schenkein, H. 2006. Periodontal diseases. In: Lamont RJ, Burne RA, Lantz MS, Leblanc DJ. Oral Microbiology and immunology. Washington DC: ASM Press, 253-294

Haffajee, A.D., \& Socransky, S.S. 1994 Microbial etiological agents of destructive periodontal diseases. Periodontology 2000, 5, 78-111. http://dx.doi.org/10.1111/j.1600-0757.1994.tb00020.x

Hirunpanich, V., Utaipat, A., Morales, N.P., Bunyapraphatsara, N., Sato, H., Herunsale, A. \& Suthisisang, C. 2005. Antioxidant effects of aqueous extract from dried calyx of Hibiscus sabdariffa Linn. (Roselle) in vitro using rat lowdensity lipoprotein (LDL). Biol. Pharm. Bull, 28(3), 481-484. http://dx.doi.org/10.1248/bpb.28.481

Hirunpanich, V., Utaipat, A., Morales, N.P., Bunyapraphatsara, N., Sato, H., Herunsale, A. \& Suthisisang, C. 2006. Hypocholesterolemic and antioxidant effects of aqueous extracts from the dried calyx of Hibiscus sabdariffa L. in hypercholesterolemic rats. Jethpharm, 103, 252-260. http://dx.doi.org/10.1016/j.jep.2005.08.033

Ikigai, H., Nakae, T., Hara, Y., \& Shimamura, T. 1993. Bactericidal catechins damage the lipid bilayer. Biochimia et Biophysica Acta, 1147, 132-136 http://dx.doi.org/10.1016/0005-2736(93)90323-r

Imamura, T. 2003 The role of gingipains in the pathogenesis of periodontal $\begin{array}{lllll}\text { disease. } & J & \text { Periodontol, } & & \\ \end{array}$ http://dx.doi.org/10.1902/jop.2003.74.1.111

Irwin, C.R., \& Myrillas, T.T. 1998. The role of IL-6 in the pathogenesis of periodontal diseases. Oral Diseases, 4, 43-47. http://dx.doi.org/10.1111/j.1601 0825.1998.tb00255.x

Kadowaki, T., Yoneda, M., Okamoto, K., Maeda, K., \& Yamamoto, K. 1994 Purification and characterization of novel Arginine-specific Cysteine Proteinase (Argingipain) involved in the pathogenesis of periodontal disease from the culture supernatant of Porphyromonas gingivalis. The Journal of Biological Chemistry, 269 (33), 21371-21378

Kagnoff, M.F., \& Eckmann, L. 1997. Epithelial cells as sensors for microbial infection. J Clin Invest, 100, 6-10. http://dx.doi.org/10.1172/jci119522

Kang, M.S., Lim, H.S., Kim, S.M., Lee, H.C., \& Oh, J.S. 2011. Effect of Weisella cibaria on Fusobacterium nucleatum induced interleukin-8 production in $\mathrm{KB}$ cells. Journal of Bacteriology and virology, 41(1), 9-18. http://dx.doi.org/10.4167/jbv.2011.41.1.9

Kataoka, S., Baba, A., Suda, Y., Takii, R., Hashimoto, M., Kawakubo, T., Asao, T., Kadowaki, T., \& Yamamoto, K. 2014. A novel potent dual inhibitor of Arggingipains and Lys-gingipains as a promising agent for periodontal disease therapy. FASEB J, 28: 1-15. http://dx.doi.org/10.1096/fj.14-252130

Kesavalu, L., Chandrasekar, B., \& Ebersole, J.L. 2002. In vivo induction of proinflammatory cytokines in mouse tissue by Phorphyromonas gingivalis and Actinobacillus actinomycetemcomitans. Oral Microbiol Immunol, 17, 177-180. http://dx.doi.org/10.1034/j.1399-302x.2002.170307.x

Kida, Y., Kobayashi, M., Suzuki, T., Takeshita, A., Okamatsu, Y., Hanazawa, S. Yasui, T., \& Hasegawa, K. 2005. Interleukin-1 stimulates cytokines, prostaglandin $\mathrm{E}_{2}$ and matrix metalloproteinase-1 production via activation of MAPK/AP-1 and NF- $\mathrm{KB}$ in human gingival fibroblasts. Cytokine, 29(4), 159168. http://dx.doi.org/10.1016/j.cyto.2004.10.009

Kim, I.B., Kim, D.Y., Lee, S.J., Sun, M.J., Lee, M.S., Li, H., Cho, J.J., \& Park, C.S. 2006. Inhibition of IL-8 production by green tea polyphenols in human nasal fibroblasts and A 549 epithelial cells. Biol Pharm Bull, 29(6), 1120-1125. http://dx.doi.org/10.1248/bpb.29.1120

Lőhr, G., Beikler, T., Podbielski, A., Standar, K., \& Hensel, A. 2011 Polyphenols from Myrothamnus flabellifolia welw. Inhibit in vitro adhesion of Porphyromonas gingivalis and exert anti-inflammatory cytoprotective effects in KB cells. J Clin Periodontal, 38, 457-469. http://dx.doi.org/10.1111/j.1600051x.2010.01654.x

Medina, I.C.R., Debon, R.B., Molina, V.M., Villaverde, C.A., Joven, J., Menendez, J.A., Carretero, A.S. \& Gutierrez. 2009. Direct characterization of aqueos extract of Hibiscus sabdariffa using HPLC with diode array detection coupled to ESI and ion trap MS. J. Sep. Sci, 32, 3441-3448. http://dx.doi.org/10.1002/jssc.200900298

Nakao, R., Takashiba, S., Kosono, S., Yoshida, M., Watanabe, H., Ohnishi, M., \& Senpuku, H. 2014. Effect of Porphyromonas gingivalis outer membrane vesicles on gingipain-mediated detachment of cultured oral epithelial cells and immune responses. Microbes and Infection, 16, 6-16. http://dx.doi.org/10.1016/j.micinf.2013.10.005

Nakashima, T., Kobayashi, Y., Yamasaki, S., Kawakami, A., Eguchi, K., \& Sasaki, H. 2000. Protein expression and functional difference of membranebound and soluble receptor activator of NF-kappaB ligand: modulation of the expression by osteotropic factors and cytokines. Biochem. Biophys. Res Commun., 275, 768-775. http://dx.doi.org/10.1006/bbrc.2000.3379

Nakatsuka, Y., Nagasawa, T., Yumoto, Y., Nakazawa, F., \& Furuichi, Y. 2014 Inhibitory effects of sword bean extract on alveolar bone resorption induced in rats by Porphyromonas gingivalis infection. J Periodon Res, 49, 801-809. http://dx.doi.org/10.1111/jre.12166

Nwaiwu, N.E., Mshelia, F., \& Raufu, I.A. 2011. Antimicrobial activities of crude extracts of Moringa oleifera, Hibiscus sabdariffa and Hibiscus esculentus seeds against some enterobacteria. J. Appl. Phytotechnol. Environ. Sanit., 1(1), 11-16. http://dx.doi.org/10.5897/jmpr11.62

Okada, H., \& Murakami, S. 1998. Cytokine expression in periodontal health and disease. Crit Rev Oral Biol Med, 9(3), 248-266 http://dx.doi.org/10.1177/10454411980090030101

Olaleye \& Tolulope, M. 2007. Cytotoxicity and antibacterial activity of methanolic extract of Hibiscus sabdariffa. Journal of Medicinal Plants Research 1(1), 009-013

Olsen, I., \& Potempa, J. 2014. Strategies for the inhibition of gingipains for the potential treatment of periodontitis and associated systemic diseases. Journal of Oral Microbiology, 6: 24800. http://dx.doi.org/10.3402/jom.v6.24800

Pike, R., McGraw, W., Potempa, J., \& Travis, J. 1994. Lysine- and Argininespecific proteinases from Porphyromonas gingivalis, isolation, characterization, and evidence for the existence of complexes with hemagglutinins. The Journal of Biological Chemistry, 269 (1), 406-411

Potempa, J., Banbula, A., \& Travis, J. 2000. Role of bacterial proteinases in matrix destruction and modulation of host responses. Periodontology 2000, 24 153-192. http://dx.doi.org/10.1034/j.1600-0757.2000.2240108.x

Rodrigues, M.M.R., Plaza, M.L., Azeredo, A., Balaban, M.O., \& Marshall, M.R 2011. Physicochemical and phytochemical properties of cold and hot water extraction from Hibiscus sabdariffa. Journal of Food Science, 76(3), 428-435. http://dx.doi.org/10.1111/j.1750-3841.2011.02091.x

Sandros, J., Karlsson, C., Lappin, D.F., Madianos, P.N., Kenane, D.F., \& Papapanon, P.N. 2000. Cytokine responses of oral epithelial cell to Porphyromonas gingivalis infection. J Dent Res, 79(10), 1808-1814 http://dx.doi.org/10.1177/00220345000790101301

Slots, J., \& Ting, M. 1999. Actinobacillus actinomycetemcomitans and Porphyromonas gingivalis in human periodontal disease: occurrence and treatment. Periodontology 2000, 20, 82-121. http://dx.doi.org/10.1111/j.16000757.1999.tb00159.x

Sulistyani, H., Fujita, M., Miyakawa, H., \& Nakazawa, F. 2016. Effect of roselle calyx extract on in vitro viability and biofilm formation ability of oral pathogenic bacteria. Asian Pacific Journal of Tropical Medicine, 9(2), 119-124 http://dx.doi.org/10.1016/j.apjtm.2016.01.020

Tsai, T.C., Huang, H.P, Chang, Y.C., \& Wang, C.J. 2014. An anthocyanin-rich extract from Hibiscus sabdariffa Linnaeus inhibits $N$-Nitrosomethylurea-induced leukemia in rats. J. Agric. Food Chem., 62, 1572-1580. http://dx.doi.org/10.1021/jf405235j

Verri Jr, W.A., Vincentini, F.T.M.C., Baracat, M.M., Georgetti, S.R., Cardoso, R.D.R., Cunha, T.M., Ferreira, S.H., Cunha, F.Q., Fonseca, M.J.V., \& Casagrande, R. 2012. Flavonoids as anti-inflammatory and analgesic drugs: Mechanisms of action and perspectives in the development of pharmaceutical forms. In: Rahman A. Studies in Natural Products Chemistry: Bioactive Natural Products (Part P). Elsevier B.V., 297-330. http://dx.doi.org/10.1016/b978-0-44453836-9.00026-8

Yamanaka, A., Kouchi, T., Kasai, K., Kato, T., Ishihara, K., \& Okuda, K. 2007. Inhibitory effect of cranberry polyphenol on biofilm formation and cysteine proteases of Porphyromonas gingivalis. J Periodont Res, 42, 589-592. http://dx.doi.org/10.1111/j.1600-0765.2007.00982.x

Yang, L., Gou, Y., Zhao, T., Zhao, J., Li, F., Zhang, B., \& Wu, X. 2012 Antioxidant capacity of extracts from calyx fruits of roselle (Hibiscus sabdariffa L.) Afr. J. Biotechnol., 11(17), 4063-4068. DOI: 10.5897/AJB11.2227

Yumoto, H., Nakae, H., Fujinaka, K., Ebisu, S., \& Matsuo, T. 1999. Interleukin-6 (IL-6) and IL-8 are induced in human oral epithelial cells in response to exposure to periodontopathic Eikenella corodens. Infection and immunity, 67(1), 384-394 